\title{
Urban Youth Culture in Bangladesh under the Sway of Cultural Globalization: A Descriptive Analysis
}

\author{
Muhammad Zakir Hossin 1*, Mohammad Mohiuddin'2 \\ ${ }^{1}$ Centre for Health Equity Studies (CHESS), Stockholm University, Stockholm, Sweden \\ ${ }^{2}$ Department of Sociology, University of Chittagong, Chittagong, Bangladesh \\ Email: ${ }^{*}$ ziku133@gmail.com
}

Received 15 June 2015; accepted 21 July 2015; published 24 July 2015

Copyright (C) 2015 by authors and Scientific Research Publishing Inc.

This work is licensed under the Creative Commons Attribution International License (CC BY). http://creativecommons.org/licenses/by/4.0/

(c) (i) Open Access

\begin{abstract}
This is a descriptive cross-sectional study which aims to present the contemporary youth culture in Dhaka, the capital city of Bangladesh, with an emphasis on the underlying role of cultural globalization. To meet the objective of the study, a survey was conducted in 2012 among the students of three leading private universities in Dhaka city. The central theme of the study revolves around the idea that globalization as a process transforms our cultures and affects our lives wherever we live. There has been a heated debate among the researchers on the issue of media effects on the youths. The debate mainly centers around the question: Does what our young generation watch on the global media really influence their behaviors and choices, or the norms and values associated with those behaviors and choices are strictly learned through the guidance of parents, teachers, peers, and the society at large? This study documents that the global media have large-scale impact on the audiences who are exposed to them. As the survey findings indicate, the urban youth culture in Bangladesh is no longer identical to her long-standing traditional patterns but is found to be melting into western norms of dress-codes, food habits, attitude, and life styles. The study demonstrates that the young generation in urban Bangladesh prefers trendy clothes, fast food, western style of marriage and family, western music, movies, festivals, and so on, reflecting a shift toward a consumer culture with global values.
\end{abstract}

\section{Keywords}

Globalization, Culture, Media, Global Culture, Youth Culture

\footnotetext{
${ }^{*}$ Corresponding author.
} 


\section{Introduction}

In this era of globalization, people from different parts of the world simultaneously experience the same events thanks to the advances in communications technology. Today the satellite broadcasting services allow an unprecedented diversity of choices for their viewers. While the media systems were primarily national in the past, in the 1990s the societies throughout the world witnessed the emergence of a global commercial media market through which the media giants established their powerful distribution and production networks within and across the national boundaries (McChesney, 2005). This media globalization, broadly known as cultural globalization, has profound implications for the way we make sense of our own lives and of the changing society we live in.

Today the Internet, satellites and cable television have swept away the cultural boundaries, with the global entertainment companies shaping the perceptions and dreams of the ordinary citizens wherever they live. This rapid spread of values, norms, and culture promotes the western ideals of capitalism. Consequently, the local culture inevitably falls victim to the global consumer culture. The multinational corporations are taking the lead in order to establish themselves and ensure their dominant presence in almost every sector of the global capitalist market. Coca Cola, McDonalds, and Nike provide with some glaring examples of such growths and proliferations. In the whole scenario, the media play the leading role of advertisers where the benefits of new products and services are shown as superior to what the local market has. And slowly but steadily the food that the peoples eat, the clothes they wear, and the life-styles they lead begin to change (Tomlinson, 1999; 2006).

The arrival of a powerful global media-driven culture shapes the processes of socialization, the norms, beliefs, and values of the young people and influences their decisions about life-style choices and behaviors. The global media offer a culture which is rich in information, full of pleasure, and endowed with relative autonomy, all of which are of particular appeal to a society's youth. This carries substantial implications not only for the lives of young people themselves but also for their relationships within the family and the larger society. As a result, the sphere of experience for many young people has become global and local at once (Suoronta, 2004).

As far as the media flow in Bangladesh is concerned, the speed of social and cultural changes is unprecedented in the country's history due to the rapid advances in communications technology. Ever since 1990, Bangladesh has been undergoing unprecedented changes in the sphere of its culture (Kalam, 2002). The advent of satellite television has made the local urban culture blended with the global cultural trends and global values. The blending of the local youth culture with a global culture is primarily shaped by the familiar Western themes and values imported via the global mass media, especially the satellite television (Shamsher \& Abdullah, 2012; Zahid, 2007).

\section{Objectives}

Drawing on empirical data, the present paper attempts to capture a snapshot of the contemporary urban youth culture in Dhaka city and to ascertain the extent to which the social and cultural life of the urban youths has been penetrated by the global flow of culture. In particular, the following specific objectives guided this study:

- To find out the nature and extent of media consumption among the urban youths in Bangladesh.

- To describe the extent to which the life-style choices and preferences of the youths have been influenced by the global flow of culture.

- To explore the attitude and behavior of the youths in so far as their social relationships including love and sex affairs are concerned.

\section{Review of Literature}

\subsection{McLuhan's Media Determinism}

Marshall McLuhan, the Canadian media theorist, was the first to draw attention to the importance of culture in the globalization process in his iconic formulation of the "global village". "The medium is the message" was the famous statement by which McLuhan startled the whole world in 1964. For McLuhan (1964), it is the type of media, not the contents, by which culture is transmitted and hence forms the basis of the determining principle of culture. For instance, a society where satellite television plays an important part is very different from the one that relies on the printed word carried aboard an ocean liner (Giddens, 2009).

For McLuhan (1964), the concept of media refers to any means of extending the senses and therefore includes technologies of both transportation and communication. His ideas of cultural process largely echoed Durkheim’s 
views on mechanical and organic solidarities corresponding to two different historical epochs. The mechanical solidarity dates back to the tribal epoch which was based on an oral culture characterized by spoken words and human experience was necessarily instant, immediate and collective. On the contrary, the organic solidarity in the industrial epoch was accompanied by technologies of printing machine, paper, roads, and so on, having a large-scale globalizing effect (Baten, 2008). This is what Giddens (1990) later called "time-space distanciation" characterized by an unprecedented capacity to speed up communications and connect distant localities. The reorganization of space through time, according to McLuhan, was further accompanied by two other important universalizing devices-the mechanical clock and money as symbolic token (Baten, 2008).

The current circumstances constitute a further epochal shift, with the electronic media accelerating the communication network and thereby extending the local culture to global scale. As McLuhan states, "Today, after more than a century of electric technology, we have extended our central nervous system in a global embrace, abolishing both space and time as far as our planet is concerned" (McLuhan, 1964: p. 3). This acceleration of electric communication and rapid transition brings about a structural effect that McLuhan calls "imposition". According to him, the effects of technology do not occur at the level of opinions or concepts, but steadily and uninterruptedly alter the "sense ratios" i.e., the patterns of perception. That is, what McLuhan is trying to point out is that the communication media affect our habits of perception and thinking more than anything else (Baten, 2008).

\subsection{Globalization and Culture: Theoretical Debates}

In the modern society, globalization and culture are interconnected and are reinforced by each other. As Tomlinson (1999: p. 1) has so well described it: "globalization lies in the heart of modern culture; cultural practices lie in the heart of globalization". Globalization, as argued by Tomlinson, is a rapidly growing network of interconnections and dependencies that form the basis of modern social life. This increasing connectivity, which constitutes an important element of modern culture, is reflected in our everyday routine practices such as in our use of communication technologies like mobile phones and computers, in the environment we live in, in the type of food we consume and in the way we entertain ourselves in cinema, television and so on. It is therefore pretty obvious that we are living in a much more globally "connected" world today than ever before (Tomlinson, 2006). And all of these have significant implications for the cultures around the world. This gives rise to the question: Are all cultures inevitably being drawn into a single global culture? This is however, a question which does not have a straightforward answer. At least the following two different views are held by the globalization theorists:

\subsubsection{The Pessimistic View of Cultural Globalization}

Within the social sciences, much of the attention has so far been focused on the negative effects of globalization on culture. According to Giddens (1990: p. 18), the dominance of the Western cultural ideals accelerated by the global networks of communication and economic exchange 'diminishes the grip of local circumstances over peoples' lives'. With the advent of globalization, traditional livelihoods and local communities have been dislocated and threatened environmental sustainability and cultural diversity have been threatened (World Commission on the Social Dimension of Globalization, 2004). When globalization is viewed as a process of cultural homogenization or Westernization or Americanization, the fear of loss of cultural diversity becomes particularly pronounced. With increased cross-border interactions, local cultures are melting down and being blended with global norms, ideas and practices (Naidoo, 2007). According to Pieterse (1994; cited in Naidoo, 2007), cultural homogenization is the belief that the so-called global culture is dictated by the global economy leading to such phrases as "Coca-colonization" and "McDonaldization" which refer to the "worldwide homogenization of societies through the impact of multinational corporations".

With the rise of the Internet and other information technologies, this view of cultural homogenization has been further consolidated. The newer forms of information technology-the mobile phones, computers and the Internet, for instance-have made the world a smaller place that directs the young people toward exploring their favorite actors and events. As Giddens (1990: p. 187) points out, youths have "phenomenal worlds that are for the most part truly global”. This means that as part of developing a global identity, the young people develop a sense of belonging to a worldwide culture which incorporates an awareness of the events, practices, styles and information that are integral parts of the global culture (Naidoo, 2007).

\subsubsection{The Optimistic View of Cultural Globalization}

The above arguments represent, of course, only one side of the logic of globalization and culture. Though globa- 
lization is often claimed to be destructive of cultural identity, Tomlinson (2005) holds the view that this argument is fundamentally mistaken. Globalization, according to him, is "the most significant force in creating and proliferating cultural identity”. Tomlinson contends that the intensification of the process of globalization happens to be associated with a parallel rise of social movements based around identity such as gender, sexuality, religion, ethnicity, etc. This has to be partly understood as a result of processes internal to globalization. Tomlinson (1999) further believes that the young people are not just passive recipients of media messages; they, of course, interpret the global media through the lens of their own cultural experiences.

Thompson (2005: pp. 256-257) on his part investigated "the creative interface between the globalized diffusion of media products and their localized appropriation”. He concludes by arguing that although globalization has altered certain aspects of the life-conditions of people throughout the world, it has not done so blatantly at the expense of local and national cultures. The importance that the media outputs carry for the individuals extensively relies on "the contexts of reception and on the resources that recipients bring to bear on the reception process". He emphasizes as well that the localized appropriation of global media products may potentially result in tensions and conflicts. While the global media products are likely to expand people's horizons of knowledge and understanding, they may simultaneously lead to tensions between local, national and global forces.

Advocating the concept of "glocalization", Robertson (2004) stressed that globalization necessarily involves an emphasis on the local. What is known as global can be located anywhere on the globe and can, for this very reason, be used to explain a localization of the global. For all those who contend that a global culture is emerging, Smith's (2005) scholarly article perhaps poses the biggest intellectual challenge. He suggests that the notion of a global culture is simply vague and imprecise and there is very little evidence of national cultures being diluted in favor of the so-called global culture. Smith confidently argues that any kind of global culture superseding the local cultures throughout the world is highly unlikely in spite of the recent global shifts in the technical and linguistic infrastructures of communications.

\subsection{Evidence of Global Media Impact}

While much is being said about the negative consequences of global media on the children and youths, the empirical evidence supporting the claim is relatively limited. Up until today, only a handful of studies have assessed the impact of foreign media on the young people in developing countries. Most of these studies have used a cross-sectional study design, having no control group to monitor changes over time. Therefore, no strong causal association with regard to globalization's impact on local cultures can be inferred.

A survey study in Greece examining the impact of media on culture among 508 students aged 15 - 19 reveals that young people spent on average about three hours a week watching US television shows. The heavy television viewers tended to have a favorable attitude toward foreign consumer goods (Zaharopoulos, 2003). In another study, researchers from several countries surveyed a total of nearly 2000 university students in China, Hong Kong, Indonesia, Japan, Germany, Great Britain, the Netherlands, and Spain. Respondents were asked how they perceived the influence of American media. The study aimed to test the hypothesis that foreign media inflict harmful effects on indigenous cultures. Findings reveal that significant geographical differences exist regarding the perceived influences of the foreign media. In the Asian countries, for example, the majority students believed that American media had a positive influence. To the contrary, the European youths surveyed perceived a negative influence from American media. Both Asian and European youths, however, shared the belief that they were negatively influenced by the violence portrayed in American media (Willnat et al., 2002). Another study based on a survey of 600 adolescents in Singapore concluded that the young people develop their own culture as part of establishing independence from their parents under the direct influence of the American media (Wee, 1999). In Bangladesh, a study conducted among students in the metropolitan city of Dhaka shows that almost half of the respondents wished to practice events shown in the foreign programs in their real lives. They wanted to be as romantic towards their beloved ones as the lovers in films or drama. Sometimes they wished to revolt against their parents' restrictions as they saw in films or serials (Zahid, 2007).

\section{Methods}

\subsection{Study Subjects}

The sample of this study consists of the urban youths who are studying in the private universities of Dhaka, the 
capital city of Bangladesh. Youths generally comprise the most technologically literate sector of our society, and therefore, are actively targeted by the multinational corporations that trade in global media commodities. That is why the youths have been selected as the target population for the present study. Again, the students of private universities have been approached because they have better and easier access to modern cultural products than their counterparts in public universities.

The study was conducted in three leading private universities in Dhaka City-The North South University (NSU), American International University of Bangladesh (AIUB), and East West University (EWU). These universities have been selected as study areas as most of the students here are from middle class upward and most of them are from business class families, which indicate that they are well-to-do in finance. Also, the students at these universities have the reputations of being fashionable and modern. In general, when people in Bangladesh hear the name of NSU or EWU or AIUB, they think of rich kids. And the survey data have verified such claims.

\subsection{Sampling}

The study involves non-probability sampling technique to draw the sample from the target population. The researchers opted for purposive sampling technique in selecting the respondents, with the only criteria of the respondents being the students of the selected universities. The total number of respondents was 123 comprising both males and females.

\subsection{Study Instrument}

Questionnaire was used as the sole data collection instrument for this study. For collecting the necessary information, a semi-structured questionnaire with a series of close- and open-ended questions was used. Most of the questions were derived from the previously published study of Zahid (2007). The language in the questionnaire was English and was made as simple as possible. The questionnaire included the socio-economic and demographic characteristics of the respondents, the nature and extent of satellite exposure and the Internet use among them, their personal tastes, preferences and habit in relation to life-style choices as well as their love and sexual affairs (Appendix).

\subsection{Data Collection and Analysis}

The field work for the present study was conducted during June-July, 2012. The respondents were approached through the help from the familiar students. In particular, extensive cooperation was received from three female students in collecting information from the female respondents. Instead of face-to-face interview, self-administrated questionnaire was chosen to ensure that the respondents might not feel ashamed, embarrassed, or afraid of giving honest answers where their personal issues were concerned. Moreover, the respondents were ensured that the information they would provide would be kept in strict confidence. The respondents' consent to participate in the study was sought during data collection. Though most of the questions in the questionnaire were close-ended, the whole questionnaire was left for appropriate post-coding. After the completion of editing and coding, the filled-in questionnaires were entered in the SPSS software with tabulation plan for processing. Both frequency tables and crosstabs were utilized in order to analyze the data.

\section{Results}

\subsection{Background Characteristics}

A total of 123 students, comprising both males (54.5\%) and females (45.5\%), participated in this study. The age of the respondents ranged between 18 to 25 years and their mean age was 22 years. Most of the study participants were Muslims (88.6\%) by religion which reflects the actual proportion of Muslims in the total population of Bangladesh. More than half of the respondents (56.1\%) of this study came from business-class families while the others came from different other occupational backgrounds including government and non-government services. Out of the total respondents in the sample, $10.6 \%$ had an income of less than 20,000 taka while more than one quarter (26.8\%) of the respondents' families belonged to the income group of 20,000 - 40,000 taka and almost a similar proportion (25.2\%) of the respondents' families earned TK. 1 lakh or more per month (Table 1). 
Table 1. Sociodemographic profile of the study participants $(n=123)$.

\begin{tabular}{|c|c|c|}
\hline & $\mathrm{n}$ & $\%$ \\
\hline \multicolumn{3}{|l|}{ Age } \\
\hline$<20$ & 10 & 8.1 \\
\hline $20-24$ & 107 & 87.0 \\
\hline $25+$ & 6 & 4.9 \\
\hline \multicolumn{3}{|c|}{ Mean $=22, \mathrm{SD}=1.68$, range $=(18-25)$} \\
\hline \multicolumn{3}{|l|}{ Sex } \\
\hline Male & 67 & 54.5 \\
\hline Female & 56 & 45.5 \\
\hline \multicolumn{3}{|l|}{ Religion } \\
\hline Islam & 109 & 88.6 \\
\hline Hinduism & 9 & 7.3 \\
\hline Christianity & 2 & 1.6 \\
\hline Buddhism & 3 & 2.4 \\
\hline \multicolumn{3}{|l|}{ Marital status } \\
\hline Married & 8 & 6.5 \\
\hline Unmarried & 115 & 93.5 \\
\hline \multicolumn{3}{|l|}{ Father's occupation } \\
\hline Govt. service & 27 & 22.0 \\
\hline Non-govt. service & 10 & 8.1 \\
\hline Business & 69 & 56.1 \\
\hline Retired & 15 & 12.2 \\
\hline Unemployed & 2 & 1.6 \\
\hline \multicolumn{3}{|c|}{ Monthly family income (in TK.) } \\
\hline$<20,000$ & 13 & 10.6 \\
\hline $20,000-40,000$ & 33 & 26.8 \\
\hline $40,000-60,000$ & 24 & 19.5 \\
\hline $60,000-80,000$ & 14 & 11.4 \\
\hline $80,000-100,000$ & 8 & 6.5 \\
\hline $100,000+$ & 31 & 25.2 \\
\hline
\end{tabular}

\subsection{Exposure to Electronic Media and Computer Technology}

The study assessed exposure to electronic media by asking respondents whether they watched foreign or local television channels, the programs they liked most, the amount of time they spent watching satellite channels, accessing the Internet, and so on. The study reveals that majority of the respondents (64.2\%) used to watch both local and foreign satellite channels. A substantial number of respondents (30.9\%) reported that they watched only foreign satellite channels while a small proportion (4.9\%) watched only local satellite channels. Moreover, $57.7 \%$ of the respondents spent on an average 1.5 to 3 hours a day watching satellite channels and around $25 \%$ watched satellite channels for more than 3 hours a day. The study further reveals that out of the programs the respondents usually watched, the most favorite was romance and sex (33.3\%). The second most favorite program was films and drama (26.8\%), followed by comedy (15.4\%), and adventure and action (14.6\%) respectively. Besides, only 6.5\% respondents preferred information and knowledge and only 3.3\% youths preferred 
sports as their most favorite television programs. Most of the respondents (74.0\%) believed that they were influenced by the programs they watched on the television while about one quarter of them (26.0\%) said that the foreign programs did not have any influence on them.

The study also shows that around $92 \%$ of the study participants had their own computes. Most of them (79.6\%) reported that they used to allocate less than 7 hours per week for academic purpose in so far as their use of computer is concerned. Only $1.8 \%$ of the respondents reported that they used to allocate more than 14 hours a week for this purpose. On the other hand, $42.5 \%$ young people used computer less than 2 hours, $33.6 \%$ used for 2 to 5 hours, $14.2 \%$ used for 5 to 8 hours and 9.7\% youths used computer for more than 8 hours on a daily basis for the purpose of recreation. Overall, the respondents were not serious about their studies as more than $80 \%$ of them reported that they normally studied less than two hours a day. Moreover, $83.7 \%$ of the respondents used to access the Internet and as many as $68.3 \%$ admitted that they were in the habit of watching pornographic films and pictures (Table 2).

\subsection{Consumerist Lifestyle}

Asked about what type of food they preferred, more than two-thirds (69.9\%) of the respondents answered fast food while only $30 \%$ of respondents preferred traditional food items. Girls were fonder of fast food (75\%) than the boys (65.7\%). Among our respondents, their sex status seemed to have nothing to do with their preference for Western dress-up. That means, both boys and girls were equally motivated $(65.7 \%$ of boys and $66.7 \%$ of girls) to dress up according to Western fashion. The data also indicate that females had more positive outlook towards Western outfit (66.1\%) than their male counterparts (56.7\%). Besides, $85.4 \%$ of the respondents are used to listening to Western music. Once again, the proportion of female respondents who used to listen to Western music was a bit higher (89.3\%) than that of the male respondents (82.1\%). The survey findings show that Hollywood is the most favorite film-industry among the respondents (52\%), followed by Bollywood (44.7\%) whereas only 3.3\% respondents chose Dallywood (the film industry of Bangladesh) as their favorite film-industry. The data also indicate that whereas Hollywood was more popular among the males (58.2\% compared with $44.6 \%$ of females), Bollywood was more favorite among the females (53.6\%) than among the males (37.9\%). Almost half of the respondents (49.6\%) had the habit of going to beauty parlors. Most of them were, however, females. As the data indicate, $80.4 \%$ of the female respondents compared with only $23.9 \%$ of the male respondents were used to going to beauty parlors.

It was reported that majority of the respondents (60.2\%) preferred affair marriage while 33.3\% preferred arranged marriage. A small proportion of the respondents (6.5\%) preferred neither type of marriage. Moreover, about $55 \%$ of the respondents were of the opinion that pre-marital or extra-marital relationship (live together) is acceptable while $45.5 \%$ did not approve of it. Responding to the question about which cultural festival was more important to them, $40.7 \%$ of the respondents cited "Valentine's Day" against $26.8 \%$ who preferred Pahela Falgun, a Bengali festival which heralds the advent of the spring season and is observed just on the day before the Valentine's Day. A significant proportion (32.5\%) also said they liked neither (Table 3).

\subsection{Love and Sex Affairs}

The majority of the respondents (63.4\%) said they freely mixed with their friends of opposite sex while 36.6\% said they did not. Besides, more than two-thirds (75.6\%) of the respondents had either a single lover affair (33.3\%) or more than one affair (42.3\%). The data indicate that the females are more committed to their love partners than their male counterparts, as around $40 \%$ of females compared to $25.4 \%$ of males have ever been in love with one single person. Again, whereas the proportion for female respondents having series of love affair is $35.7 \%$, the corresponding figure of males having such relation is $47.8 \%$. Of the respondents who reported to have ever been in love, either single or multiple, more than half (52.7\%) admitted to have had sex with their love partners (Table 4).

\section{Discussion}

From the research findings stated above, it can be established that mass media as a powerful tool of globalization do affect the local youth culture of urban Bangladesh (Shamsher \& Abdullah, 2012; Zahid, 2007). The study clearly reveals that the urban youth culture in Bangladesh is no longer identical to her long-standing 
Table 2. Satellite exposure, computer use, and reading habit $(\mathrm{n}=123)$.

Type of TV channels watched

$\begin{array}{ccc}\text { Local } & 6 & 4.9 \\ \text { Foreign } & 38 & 30.9 \\ \text { Both local and foreign } & 79 & 64.2\end{array}$

Exposure to satellite TV (daily in hrs)

$\begin{array}{ccc}<1.5 & 22 & 17.9 \\ 1.5-3.0 & 71 & 57.7 \\ \text { and/or above } & 30 & 24.4\end{array}$

Favorite TV program

$\begin{array}{lcc}\text { Films and drama } & 33 & 26.8\end{array}$

Comedy

$19 \quad 15.4$

Romance and sex

33.3

Adventure and action

41

14.6

Information and knowledge

Sports

Influenced by TV program

Yes

No

Personal computer

Yes

No

Academic use of computer (weekly in hrs) $(\mathrm{n}=113)$

$<7$

$7-14$

14 and/or above

Computer use as recreation (daily in hrs) $(n=113)$

$<2$

$2-5$

$5-8$

8 and/or above

\section{Access to Internet}

Yes

No

Accessing pornography

$$
\text { Yes }
$$

No

Reading habit (daily in hrs)

$\begin{array}{cc}<2 & 9 \\ 2 & -5 \\ 5 & -8 \\ \text { and/or above } & 6\end{array}$

$2 \quad 1.6$

$6 \quad 4.9$


Table 3. Preference of western cultural practices by sex $(n=123)$.

\begin{tabular}{|c|c|c|c|c|c|c|}
\hline & \multicolumn{4}{|c|}{ Sex } & \multirow{2}{*}{\multicolumn{2}{|c|}{ Total }} \\
\hline & \multicolumn{2}{|c|}{ Male } & \multicolumn{2}{|c|}{ Female } & & \\
\hline & $\mathrm{n}$ & $\%$ & $\mathrm{n}$ & $\%$ & $\mathrm{n}$ & $\%$ \\
\hline \multicolumn{7}{|l|}{ Type of food preferred } \\
\hline Fast food & 44 & 65.7 & 42 & 75.0 & 86 & 69.9 \\
\hline Traditional food & 23 & 34.3 & 14 & 25.0 & 37 & 30.1 \\
\hline \multicolumn{7}{|l|}{ Wearing western dress-up } \\
\hline Yes & 44 & 65.7 & 38 & 66.7 & 82 & 66.7 \\
\hline No & 23 & 34.3 & 18 & 32.1 & 41 & 33.3 \\
\hline \multicolumn{7}{|l|}{ Listening to western music } \\
\hline Yes & 55 & 82.1 & 50 & 89.3 & 105 & 85.4 \\
\hline No & 12 & 17.9 & 6 & 10.7 & 18 & 14.6 \\
\hline \multicolumn{7}{|l|}{ Favorite film industry } \\
\hline Hollywood & 39 & 58.2 & 25 & 44.6 & 64 & 52.0 \\
\hline Bollywood & 25 & 37.3 & 30 & 53.6 & 55 & 44.7 \\
\hline Dallywood & 3 & 4.3 & 1 & 1.8 & 4 & 3.3 \\
\hline \multicolumn{7}{|l|}{ Going to beauty parlors } \\
\hline Yes & 16 & 23.9 & 45 & 80.4 & 61 & 49.6 \\
\hline No & 51 & 76.1 & 11 & 19.6 & 62 & 50.4 \\
\hline \multicolumn{7}{|c|}{ Preferred marriage system } \\
\hline Arranged marriage & 21 & 31.3 & 20 & 35.7 & 41 & 33.3 \\
\hline Affair marriage & 41 & 61.2 & 33 & 58.9 & 74 & 60.2 \\
\hline Neither & 5 & 7.5 & 3 & 5.4 & 8 & 6.5 \\
\hline \multicolumn{7}{|l|}{ Attitude to "live-together" } \\
\hline Positive & 35 & 52.2 & 32 & 57.1 & 67 & 54.5 \\
\hline Negative & 32 & 47.8 & 24 & 42.9 & 56 & 45.5 \\
\hline \multicolumn{7}{|l|}{ Choice of cultural festival } \\
\hline Valentine’s day & 28 & 41.8 & 22 & 39.3 & 50 & 40.7 \\
\hline Pahela falgun (spring) & 17 & 25.4 & 16 & 28.6 & 33 & 26.8 \\
\hline Neither & 22 & 32.8 & 18 & 32.1 & 40 & 32.5 \\
\hline
\end{tabular}

Table 4. Love and sex affairs of the study participants by sex $(\mathrm{n}=123)$.

\begin{tabular}{|c|c|c|c|c|c|c|}
\hline & \multicolumn{4}{|c|}{ Sex } & \multirow{2}{*}{\multicolumn{2}{|c|}{ Total }} \\
\hline & \multicolumn{2}{|c|}{ Male } & \multicolumn{2}{|c|}{ Female } & & \\
\hline & $\mathrm{n}$ & $\%$ & $\mathrm{n}$ & $\%$ & $\mathrm{n}$ & $\%$ \\
\hline \multicolumn{7}{|l|}{ Free-mixing with opposite sex } \\
\hline Yes & 41 & 61.2 & 37 & 66.1 & 78 & 63.4 \\
\hline No & 26 & 38.8 & 19 & 33.9 & 45 & 36.6 \\
\hline \multicolumn{7}{|l|}{ Number of love affair } \\
\hline Affair with one person & 17 & 25.4 & 24 & 42.9 & 41 & 33.3 \\
\hline Affair with more than one person & 32 & 47.8 & 20 & 35.7 & 52 & 42.3 \\
\hline No affairs & 18 & 26.9 & 12 & 21.4 & 30 & 24.4 \\
\hline \multicolumn{7}{|l|}{ Physical relation with lovers $(n=93)$} \\
\hline Yes & 24 & 49.0 & 25 & 56.8 & 49 & 52.7 \\
\hline No & 25 & 51.0 & 19 & 43.2 & 44 & 47.3 \\
\hline
\end{tabular}


traditions but is found to be fused with Western norms of dress-codes, food habits, attitudes, and life style. Being heavily exposed to the globalized symbolic materials through the modern-day media like cable television and the Internet, the youths of this country appear to feel quite spontaneous and enthusiastic to incorporate them into the routines and practices of their daily lives.

The study has found that most of the respondents use media as a means of entertainment rather than gathering knowledge. They use their personal computer for playing games, chatting, listening to songs or e-mailing. Very few respondents were found sincere about their studiers. The study also found that romance and sex are the most preferred programs among the youths followed by films and drama. The foreign programs which are shown through satellite televisions actually expose the Western culture in terms of life-styles, values, and attitude. Being influenced by what they watch through these programmers, our young generation have also started to practice those life-styles, integrating those values and attitudes. The age-old Bengali festivals, the spring festival for example, are less important to them than the Western festivals of Valentine's Day and the like. It is also revealed that this generation mostly prefer love-affair marriage to form their family. Even sexual relation is not absent among them; they get engaged in sexual activities under the pretext of love. All these findings are largely consistent with a similar survey carried out earlier by Zahid (2007).

The survey findings made it apparent that the modern global media combined with information and communication technology powerfully influence the lives of young people, thereby creating a global media-driven youth culture. No matter if it is called "Americanizatin" or "Westernization" or "cultural globalization", the driving forces behind this homogenization of culture are the mass media. Controlled mainly by American or European companies, the media impose their powerful images, sounds and advertising on unprepared peoples of the globe in a way that only boosts the interests of capitalist organizations (Lechner \& Boli, 2004). In fact, at its most profound level, cultural globalization accelerates the development of a monolithic consumer culture that appears to encourage a global vision of the world. This includes the culture of Hollywood/Bollywood movies, fast food, rock music and so on (Kalam, 2002). Bangladesh is equally in the grip of this cultural hegemony as it is also a member of this electronic media society where most of the urban people are used to almost every form of media (Zahid, 2007). The present study echoes this same reality. As the findings suggest, the young people in Bangladesh have now acquired a distinctive social identity, with their own tastes in food habits, clothing, entertainment, and so on. Because of the influx of foreign culture into our society, a particular youth culture has been created in terms of their choices, behaviors, attitude, and lifestyles.

\section{Conclusion}

The impact of cultural globalization on the lifestyle and behavior of the young people is still an issue of controversy. The incorporation of media technology into the daily life of youths can, in fact, have both positive and negative consequences. The objective of this study, however, was devoid of such value judgment; rather it was an attempt to only present the existing youth culture as it was, which was assumed to be a creation of the global media in general and the satellite television in particular. A distinctive urban youth culture does exist in our contemporary society in which global media are playing a central and obvious role. All the youths, irrespective males and females, are heavily affected by the process of cultural globalization. However, this study may not represent the picture of the entire youth culture of urban Bangladesh due to the adoption of purposive sampling technique and the selection of a relatively small sample. In spite of such limitations, it can be hoped that this paper would be a starting point for future investigations into globalization and culture in the context of the Bangladeshi society. Future researches may add to this line of inquiry by statistically linking the process of cultural globalization to important outcome variables.

\section{References}

Baten, S. A. (2008). Globalization and Anti-Globalization. Dhaka: Pathok Shamabesh.

Giddens, A. (1990). The Consequences of Modernity. Cambridge: Polity Press.

Giddens, A. (2009). Sociology. Cambridge: Polity Press.

Kalam, A. (2002). Globalization and Bangladesh in the New Century. Dhaka: Palok Publications.

Lechner, F. J., \& Boli, J. (Eds.). (2004). The Globalization Reader. Australia: Blackwell Publishing.

McChesney, R. W. (2005). The New Global Media. In D. Held, \& A. McGrew (Eds.), The Global Transformations Reader (pp. 260-268). Cambridge: Polity Press. 
McLuhan, M. (1964). Understanding Media. New York: Mentor.

Naidoo, L. (2007). Rupture or Continuity? The Impact of Globalization on Cultural Identity and Education in Indian Immigrant Families in Australia. International Curriculum Inquiry, 4, 18-22. http://ojs.library.ubc.ca/index.php/tci/article/viewFile/34/69

Robertson, R. (1994). Glocalization: Time-Space and Homogeneity-Heterogeneity. In: F. J. Lechner, \& J. Boli (Eds.), The Globalization Reader. Australia: Blackwell Publishing.

Shamsher, R., \& Abdullah, M. N. (2012). Effect of Satellite Television on the Culture of Bangladesh: The Viewers’ Perception. European Journal of Business and Management, 4, 45-54. www.iiste.org/Journals/index.php/EJBM/article/download/2202/2215

Smith, A. (2005). An Introduction to Globalization Debate. In D. Held, \& A. McGrew (Eds.), The Global Transformations Reader. Cambridge: Polity Press.

Suoronta, J. (2004). Youth Information and Communication Technologies. In World Youth Report: The Global Situation of Young People. New York: United Nations Department for Economic and Social Welfares.

Thompson, J. B. (2005). The Globalization of Communication. In D. Held, \& A. McGrew (Eds.), The Global Transformations Reader (pp. 247-257). Cambridge: Polity Press.

Tomlinson, J. (1999). Globalization and Culture. Cambridge: Polity Press.

Tomlinson, J. (2005). Globalization and Cultural Identity. In D. Held, \& A. McGrew (Eds.), The Global Transformations Reader (pp. 267-276). Cambridge: Polity Press.

Tomlinson, J. (2006). Globalization and Culture. Paper presented at the University of Nottingham, Ningbo, China, 24 November 2006.

Wee, T. (1999). An Exploration of a Global Teenage Life-Style in Asian Societies. Journal of Consumer Marketing, 16, 365375. www.emeraldinsight.com/journals.htm?articleid=856330 http://dx.doi.org/10.1108/07363769910277184

Willnat, L., He, Z., Takashi, T., \& Lopez-Escobar, E. (2002). Perceptions of Foreign Media Influence in Asia and Europe: The Third Person Effect and Media Imperialism. The International Journal of Public Opinion Research, 14, 175-192. http://dx.doi.org/10.1093/ijpor/14.2.175

World Commission on the Social Dimension of Globalization (2004). Geneva: International Labor Office.

Zaharopoulos, T. (2003). Perceived Foreign Influence and Television Viewing in Greece. In M. Elasmer (Ed.), The Impact of International Television: A Paradigm Shift (pp. 39-56). Athens: LEA’s Communication.

Zahid, D. (2007). Impact of Cultural Globalization on the Upper Class Youth in Dhaka City: A Sample Study. Bangladesh e-Journal of Sociology, 4, 45-56. http://www.bangladeshsociology.org/Impact\%20of\%20Cultural\%20Globalization4.2.pdf 


\section{Appendix: The Questionnaire}

Hello!

This is a questionnaire about the urban youth culture among the students of Dhaka city. We seek your generous co-operation to answer the questionnaire carefully. Note that the questionnaire is completely anonymous and all the information provided by you will be kept strictly confidential. Data will be used only for academic purposes. If you do not feel comfortable with answering any question(s) due to their personal nature, feel free to leave them blank. However, you are requested to provide the correct answers. We would highly appreciate if we could take around 20 minutes of your time. If you have any queries, please contact ziku133@gmail.com.

Thanks in advance!

Are you willing to take part in this study? (Please circle the appropriate option.)

Yes No

Name of your institution:

\section{Section A: Demographic Characteristics}

1. Age (in complete years):

2. Gender: Male Female

3. Marital Status: Married Unmarried

4. Religion: Muslim Hindu Christian Buddhist Other (Please specify):

5. Father's Occupation:

$\begin{array}{llc}\text { Unemployed } & \text { Retired } & \text { Farmer } \\ \text { Teaching } & \text { Doctor } & \text { Advocate } \\ \text { Engineer } & \text { Business } & \text { Army personnel } \\ \text { Other }(\text { Please specify): } & & \end{array}$

Other (Please specify):

6. Gross monthly income in the family (in TK):

\section{Section B: Media Exposure}

7. Do you watch satellite television?
$\square$ Yes
No

7A. If yes, what kind of satellite channels do you watch?

$\square$ Local Foreign $\square$ Both

7B. If yes, how many hours do you watch per day? (Please note down.)

7C. If yes, what channels do you normally watch? (Please mention.)

8. What's your most favorite TV program? (Please circle only one.)

Films and drama

Comedy

Romance and sex

Adventure and action

Information and knowledge

Other (Please specify):

9. Do you think what you see on the program influences you?
Yes
No

9A. If yes, then how? (Please clarify)

10. What sort of impact do you think satellite TV has on you?
Positive
Negative
Both
Neither

11. Do you have any computer?

Yes

$\square$ No

11A. If yes, how much time do you use it for academic purpose (per week)? 
11B. If yes, how much time do you use it for recreational purpose (per day)?

12. Do you access the internet? Yes

No

12A. If yes, how many hours do you use the internet (per week)?

12B. If yes, what do you mainly use the internet for? (Please tick only one.)

Read and send e-mail

Chatting

Play games

Watch movies/listening music

Read news

Search for information

Other (Please specify):

13. Do you access pornography?

Yes

No

13A. If yes, then how often?

Often Sometimes

14. How many hours on an average do you study a day? (Please write down.)

\section{Section C: Life-Style Choices}

15. What's your preferred type of food?

Fast food

Traditional food

16. How often do you take fast food?
Often
Sometimes

Seldom

17. Do you dress up according to Western trend or fashion?

Yes

17A. If yes, how often?
Always
Sometimes

Seldom

18. Do you think western dressing style is suitable to our culture?

Yes

No

19. Why or why not (Please clarify)?

20. Do you listen to Western music? Yes

No

20A. If yes, then how often? Often Sometimes

Seldom

21. What's your favorite film industry?
Hollywood
Bollywood
Dallywood
other (Please specify)

22. Would you please say why it is favorite to you?

23. Do you go to beauty parlors?

Yes

23A. If yes, how often?

Regularly

4. What's

.

Extended

25. What type of marriage do you prefer?

Arranged marriage

Affair marriage

26. Which cultural festival is more important to you?

Valentine's Day

Pahela Falgun
Seldom

Neither

Neither

Neither 
27. Could you please say why?

\section{Section D: Love and Sex Affairs}

28. Do you have any love mate (boy/girl friend)? Yes No

28A. If yes, how many love-mates do you have? (Please write down.)

28B. If yes, have you ever had sex with your love-mate?

Yes

No

Thank you for your time and patience! 